gether political scientists interested in using computers for research and teaching as well as those interested in assessing the impact of computers on politics.

In its first official year as a section, the group offered two panels in the official program. Both included significant papers and were well attended.

Beginning in 1989 a newsletter will be published to help members share ideas and research interests. Editor Michael Vasu is soliciting submissions and ideas for permanent features. Suggestions for panel papers for the 1989 Annual Meeting may be sent to him, also. (Professor Vasu's address appears in this issue's compiled list of section officers.)

To get on the Computer Users Section mailing list, contact Stephen Frantzich, Department of Political Science, U.S. Naval Academy, Annapolis, MD 21402.

\section{Poli-ware: The Political Science Software Development Project}

\section{The Poli-ware Software Development} Project Committee met in July to begin the first round of reviews of software development projects. The committee members consist of Richard Brody, Stanford Univer. sity; Herb Asher, Ohio State University; and Donna Bahry, New York University. The committee will evaluate the substantive merit of software submissions. Technical quality will be evaluated by Carl Grafton and Anne Permaloff of Auburn University.

The Poli-ware project will narrow the review of software development projects to exclude: (1) software only addressing methodological techniques; (2) software already widely commercially available; and (3) software associated with a particular textbook or commercial software package. In the first round of evaluations, the committee members will examine five submissions.

During the next round of reviews, the committee members encourage software developers to submit programs for the following areas: the judiciary; congressional elections; the budget process; elections over time; comparative state policymaking; city or local elections; war games; international debt; comparative political violence; the welfare state; the growth of neoconservatism; national health care policy; environmental policy: energy policy; country-specific programs; and coalition formation in multi-party states. The Poli-ware program encourages the development of software in these areas at the introductory course level, though software for more advanced students will also be evaluated by the review committee.

Questions and submissions should be directed to Poli-ware APSA, $1527 \mathrm{New}$ Hampshire Avenue, N.W., Washington, DC 20036.

\section{Teachers Awarded the James Madison Fellowship}

The 200th birthday of the United States Constitution, celebrated last September. ushered in an era of programs to enhance Americans' understanding of the fundamental principles of their government. Project ' 87 initiated the James Madison Fellowship Program to identify master teachers who can work for a vital commemoration of the Constitution's Bicentennial that informs their students, colleagues, and communities.

The James Madison Fellowship is awarded, on the basis of a national competition, to outstanding junior and senior high school teachers of history and government. Each James Madison Fellow receives an award of $\$ 2,500$, support to attend a summer conference on the United States Constitution, and funds for projects in their communities and their schools.

The James Madison Fellows have prepared for their projects by participating in a summer seminar devoted to the study of the U.S. Constitution and to strategies for engaging the public, their students, and 
fellow teachers in programs on constitutional principles. The 1988 seminar for the James Madison Fellows was hosted by the Social Studies Development Center at Indiana University.

The 1988 James Madison Fellows will be following in the footsteps of an initial group of 20 teachers who have served as Fellows in 1986-87 and a larger group of 50 teachers who organized programs on the Bicentennial Year, 1987. All of these teachers established programs in communities that stretch from the Pacific Northwest through the South and up to the Far Northeast. They have prepared: features in local newspapers; special editions of student newspapers; exhibits and discussion groups in libraries; "constitution fairs" and town meetings; plays and dramatic readings; appearances on local television and radio stations. In addition, the James Madison Fellows have been sharing their knowledge and resources with their colleagues through extensive in-service workshops. The newly designated James Madison Fellows are expected to follow in their footsteps, thereby demonstrating the continuing strength of grass roots projects devoted to the Constitution's Bicentennial. The 1988 James Madison Fellows are:

Earl P. Bell, University Park, Illinois; The Laboratory Schools, University of Chicago; (3/2) 702-0588.

Donald E. Blankenbush, Pennington, New Jersey; John Witherspoon Middle School, Princeton. New Jersey; (609) $924-5600$.

Louis ]. Broccolo, New Lenox, Illinois; Central Junior High School, Tinley Park, Illinois; (3/2) 532-1771.

Sandra Shew Campbell, Arlington, Texas; Arlington High School; (817) 460-2541.

Lee A. Chase, Richmond, Virginia; Chesterfield County Public Schools, Chesterfield, Virginia; (804) 748- 1405.

James P. Garland, West Lafayette, Indiana; West Lafayette High School; (317) 743-9502.

Jeffrey A. Griffith, Fontana, California; Fontana High School; (7|4) 350-7500.

Joseph A. Lendini, Las Vegas, Nevada; Dell H. Robison Junior High School; (702) 799-7300.

Erma Gay McNinch, Brandon, Mississippi; Pearl High School, Pearl, Mississippi; (60l) 932-7931.
Shirley McDonnell, Beloit, Wisconsin; Hononegah Community High School, Rockton, Illinois; (815) 624-8951.

Edward M. Morris, Buckeystown, Maryland; Walt Whitman High School, Bethesda, Maryland; (30I) 320-5900.

Mary Murphy, State Representative, Hermantown. Minnesota; Minnesota House of Representatives, St. Paul, Minnesota: (218) 729-6399.

Michael F. Ortmann, Wichita, Kansas; Derby Middle School, Derby, Kansas; (316) 788-1559.

Linda N. Ryan, Ashland, Oregon; Co-Chair Ashland Bicentennial Committee, Liaison with Ashland School District; (503) 488-2828.

Ronald I. Savino, Simsbury, Connecticut; William H. Hall High School, West Hartford, Connecticut; (203) 232-4561.

Kenneth W. Townsend, Charlotte, North Carolina; Charlotte-Mecklenburg Schools; (704) 379-7000.

jill Wayne, Berwyn, Illinois; Kenwood Academy, Chicago, Illinois; (312) 536-8850.

\section{Tom Foley, Fred Holborn Honored at CFP Caucus Dinner}

The Honorable Thomas S. Foley was honored as the "Outstanding Legislator of the 100th Congress" and Professor Fred Holborn, of The Johns Hopkins University School for Advanced International Studies, as the "Outstanding Friend of the Program," at the third Congressional Fellowship Program Caucus. The two honorees were selected by former Fellows from among candidates nominated by the Congressional Fellowship Alumni Association's organizing committee. The awards were made at a dinner held September I at the Dupont Plaza Hotel, in Washington.

Leonard Parkinson, president of the Congressional Fellowship Alumni Association, was chairman of the event; he was assisted by Fred Clarke, vice president.

Congressional Fellowship Program caucus events are scheduled to coincide with APSA Annual Meetings held in Washington, DC. 